\title{
A Study of Minor Characters in William Shakespeare's Great Tragedies.
}

\author{
Dr. Jai Shankar Tiwari \\ Assistant Professor \\ Department of English \\ Nehru Gram Bharti (Deemed to be) University \\ Kotwa, Prayagraj, UP, India \\ drjstiwari002830@gmail.com
}

\begin{abstract}
The abstract summarizes the analysis and interpretation of the significance of minor characters in Shakespeare's major tragedies and concludes that Shakespeare is the greatest creator of characters. His greatness lies of course, in creating and heroic characters like Hamlet, Othello, Lear and Macbeth but what is significant is that even the minor characters are as immortal as the major ones. The great Villain Iago are great characters but the less important characters like Horatio, Fortinbras, Edgar, Cassio and Banquo are equally important.
\end{abstract}

Besides, Shakespeare's women characters, mostly assigned minor roles, create niche in our heart. Ophelia, Cordelia, Desdemona and Lady Macbeth have their own place. Nobody will forget them. In fact, they bring spice to the development of the plot and so do Horatio Ophelia, Lady Macbeth, Banquo, Macduff, Earl of Gloster, Edgar, Cassio and Emilia in tragedies. 
DOI: $\underline{\text { https://doi.org/10.24113/ijellh.v8i1.10384 }}$

William Shakespeare is the greatest creator of characters. There is no dramatist in the world who has such a wide range. His characters range from the most innocent to the most wicked, from the king to the beggar, from the most meditative to the jucular, from the most serious to the most comic and from the most ambitious to the most satisfied. Besides, he has created the largest number of round or complex characters. What is really significant is theat he has maintained a perfect balance between the major characters and the minor characters. A lay is an organic whole and even the minor parts have important roles to play. In a human body the head, the heart, the arms and the legs are the larger parts. The eyes, the ears and the fingers are minor parts. A blind or deaf or fingerless man can live a long life but in comparison to a well-formed body he will certainly be inferior. So is the case with a drama. If the minor characters are absent or are not fully developed, it will fail to impress the audience. Shakespeare knew it perfectly well. Emilia is a minor character in Othello but her role is of great significance. In fact minor characters function as nuts and bolts in a big machine and make it function smoothly.

The new approach to Shakespeare's method of characterization has its base in Bradley. It removes some of the drawbacks of Bradley's method and tries to explain the means by which Shakespeare has created characters who seem to be more life like than those of other dramatists.

If we examine Shakespeare's method in the old traditional way, we will find that he is not very much different from his contemporaries. He like other Elizabethan and Jacobean dramatists, creates credible characters by the actions they are made to perform. They are judged by what they say and what other people say about them. The other people are their friends, enemies and the neutral people.

King Lear serves a good example. He says many things about him and so do his daughters about him. The knights and the other people make some estimates of his character. 
DOI: https://doi.org/10.24113/ijellh.v8i1.10384

We also see him act and we find that he is a fool in the beginning but wise at the end. Our judgment is based on the action and speeches in the play.

Hamlet is a better example. He feigns madness, spares Claudius, kills Polonius, sends Rsencrantz and Guildenstern to death, grapples with Laertes at Ophelia's grave. He abuses Ophelia, says harsh words to his mother, curses himself for inordinate delay in taking revenge and envies Fortinbras, a man of action. Ophelia says that he is a noble mind, Claudius, at first, says that his mind is diseased and to Horatio he is a sweet prince. Fortinbras pays the tribute that he would have been an excellent king. Hamlet has been interpreted on these lines.

Kenneth Muir accepts Maurice Morgann's concept of "secret impressions". He writes in the essay "Shakespeare's open Secret" that ambiguities and ambivalences are an integral part of Shakespeare's method of characterization.

The "Secret impressions" take different forms. The first is the "conflicting impressions". Shakespeare usually takes a well known story or event and makes changes in such a way as the audience is surprised. The changes make the characters more real and life like.

The second feature of Shakespeare's technique is that he uses stage types as the basis of his characters. Sometimes, he fuses two or three stage types into one. The influence of morality plays is more apparent in the tragedies. It has often been shown be critics like F.P. Wilson that Shakespeare blends the influence of the metaphysical struggle between vice and virtue with a more, modern, secular, psychological characterization. Iago is a medieval evil anxious to bring Othello's soul to damnation. But he is also a character who feels that he has been wronged by Othello that Cassio has superceded him. He suffers from colour prejudice and other human motives. In other words, Shakespeare has blended the psychological and the metaphysical elements in the character of lago. Similarly he has broken the stereotypes of honest soldier and barbarous Moor. 
DOI: https://doi.org/10.24113/ijellh.v8i1.10384

The third feature of Shakespeare's art is his use of verse. It is rather difficult to differentiate characters in verse than in prose. Shakespeare's triumphs in the plays written at the end of the sixteenth century where he used prose perfectly but must have been tempted to make characters like Shylock, Falstaff, Beatrice and Rosalind speak prose. Certainly Shylock's and Rosalind's prose is charged with poetic intensity. Falstaff prose prose is memorable. Nobody can equal his humour.

Shakespeare's minor characters belong to the social aspect of the individual. Hamlet does not grow and change in isolation. There are the minor characters like Gertrude, Ophelia, Horatio and Fortinbras who change the course of hiss life. Besides, there is the ghost, the symbol or representative of the traditional notion of revenge.

Following are the characteristics of the minor characters.

1. They form a social group, usually the middle class or the lower class. Horatio belongs to the middle class but the grave digger and the soldiers to the lower class. Their views and attitudes are quite different from those of Hamlet and so is the case with the players who come to perform a play in the king's court.

2. They accelerate the action of the play. Emilia's stealing of Desdemona's handkerchief presented by Othello accelerates the play's action. The revelling mob in Romeo and Juliet delays the Friar and precipitates the tragedy of the lovers.

3. They function as comments on the main action of the plays. Casca is such a character in Julius Caesar. Emilia's words condemning Othello's action are apt and represent the audience's reaction.

4. They present a variety. The drunk porter in Macbeth gives us a comic relief. Edgar's fooling of his father is another example of comic relief. Roderigo also adds spice to the play. 
DOI: https://doi.org/10.24113/ijellh.v8i1.10384

Hamlet

Hamlet is among the very few plays in the world in which character and plot are satisfactorily coordinated. Instead of being rigidly confined to a pattern of events, the characters, both major and minor develop and take over the plot by themselves changing as the plot progresses. The minor characters in this play are certainly not puppets fitted into the various incidents and acting according to the dramatist's self-imposed demands with the plot. Their dramatic function is of great significance. They not only play a vital role in the growth of the plot but also capture our interest from the beginning to the end.

This great contribution of Shakespeare to the English drama is the splendid portraitgallery filled with so many delightful and amusing men and women. His unerring eye portrays even minor characters with great precision and exactness. The minor characters portrayed in the opening scene of Hamlet are Francisco, Bernardo, Marcellus, Horatio and the Ghost of Hamlet's father.

The opening scene of a Shakespearean drama usually gives the exposition, the statement of the condition of affairs on which the plot is based. Here, as it is often the case, the position is revealed by the talk of minor characters.

The scene is that a sentry walks high on the battlement of the royal castle at Elsinore. It begins with sharp speeches between the very nervous sentry, Francisco, and the officers, Bernardo and Marcellus who have come to relieve him of guard duty, so that they may show the ghost to their friend Horatio whom they have brought along.

In the opening scene, we make acquaintance with an important person in Hamlet's world. Horatio is Hamlet's friend and confidant and the scene tells us of his learning and his skepticism. He is a scholar and is well versed in Latin. He will not believe in the existence of Ghost until he sees it with his own eyes. At the stroke of the hour, at once, the Ghost appears. 
DOI: https://doi.org/10.24113/ijellh.v8i1.10384

The Ghost in full armour appearing in the presence of living persons, is an ominous meeting of the dead and the living. Moreover the 'warlike form' of the Ghost suggests violence.

The second scene of the first act introduces another group of personages, distinguished figures of the Danish court. In this scene we meet Hamlet, the hero, king Claudius, the villain, and a number of minor characters- Cornelius, Volman, Polonius, Laertes and Gertrude.

Gertrude, the queen of Denmark and mother of Hamlet, seems to be passive all the time, but her character is still of considerable significance. As a mother, she has a deep love for Hamlet. She protests against Hamlet's prolonged spell of depressed spirits and mourning for his father:

'Thou know'st 'tis common - all that live must die.

Passing through nature to eternity."

This scene gives a brief account of two countries, Cornelius and Voltim and. These two minor figures are dispatched on an embassage to the 'impotent and bed rid' king of Norway, who rebukes fort in bras but empowers him to use the troops to attack Poland.

At the end of the scene Horatio, Marcellus and Bernardo arrive. Horatio is especially welcomed as an old comrade at the University. It should be noticed that, Laerters had come from Paris to the coronation; Horatio from Wittenberg to the late king's funeral. Horatio gives to Hamlet an account of the appearance of the Ghost whom he and the others have seen.

The third scene introduces us to Ophelia, the heroine of the play, and sheds much valuable light on the characters of Laertes and Polonius.

Though Polonius is a minor character yet the way he plays his part clearly indicates that he is much more than that. He is at the center of affairs and respected by the royal couple despite his garrulity. He cannot resist any opportunity of giving his opinion or delivering a sermon full of platitudes. 
DOI: https://doi.org/10.24113/ijellh.v8i1.10384

In act first scene fourth we see Hamlet, Horatio and Marcellus on the platform, awaiting the appearance of the apparition. The appearance of the Ghost in the silence of the night, faintly lighted by the struggling moonbeam through clouds, brings to us an impression of mystery, desolation and fear. The Ghost makes night hideous, but uses a 'courteous action' to invite Hamlet to follow him. Horatio is afraid that the Ghost will drive the Prince mad, but Marcellus deduces from the appearance that 'something is rotten in the stage of Denmark'. This is the second prediction of impending woe.

The first scene of the second act throws some further light on the character of Polonius. Polonius has been wise with the little wisdom of wordly prudence. He has been a master of indirect means of getting the truth, "windlasses and assays of bias." Polonius' low suspiciousness, tedious garrulousness and incapacity for affairs are shown plainly in this scene.

Polonius, through a minor character, always makes his presence felt in leading the action of the play. The king honors him as his chief supporter and right hand. He is granted an old counselor's privilege. Polonius has just listened to the embassies of Voltimand and comments that the business about the prince of Norway has ended very favourably for their own country. Then in particular windy manner he tells the royal couple that it would be needless on his part to instruct them in the secrets of statecraft.

The second scene of the second act shows us an emphatic picture of minor characters and the significant part played by them in the tragedy. In this scene we are introduced to Rosencrantz and Guildenstern, who have been brought up as playmates of Hamlet.

The Gonzago plays enacted by the players, serves its purpose. The crime of Claudius stands confirmed. Rozencrantz and Guildenstern tell the Prince that the king is in his private apartment in a fury over the play Guildenstern tells Hamlet that the queen, 'In most great affliction of spirit," has sent for him. 
DOI: https://doi.org/10.24113/ijellh.v8i1.10384

The third scene of the third act shows us the striking effect the "mouse-trap" has on Claudius. He summons Rosencrantz and Guildenstern and explains to them the necessity of getting Hamlet out of Denmark to England with all speed on account of his madness and the danger of what he may do next. Both Rosencrantz and Guildenstern discourse to Claudius on the extreme importance of preserving his invaluable life.

Rozencrantz and Guildenstern are employed as spies on hamlet. The Prince is continuously watched by them. They are tools of Claudius, sent to pump Hamlet dry to his knowledge. Though they are merely tools, their role in the tragedy can not be ignored. Consequences prove that they, like the other minor characters, are an integral part of the tragedy.

In the same way the grave-digger, to Laertes and Ophelia plays significant roles in Hamlet. Without the minor characters the play would be dull and monotonous. Othello

In Othello, the minor characters are portrayed with great accuracy. The minor characters, are Duke of Venice, Brabantio, the Clown, Cassio, Bianca, Montano, Gratiano, Lodovico, Rodgerigo, and Emilia.

As compared with the other great tragedies, the number of minor characters introduced in Othello is small indeed. Hamlet, Macbeth, King Lear contain respectively 22, 30 and 17, whereas Othello contains only 10 minor characters. The lesser number of minor characters in Othello contributes to the effect and impression of power, simplicity and intensity. It does not put a strain on our attention which a large number of characters do. It makes the outline of the dramatic action plain, clear and easily followed.

Unlike King Lear, Othello has only one plot and the minor characters are fully integrated with the major characters. Roderigo, Emilia, Bianca, Brabantio, Montano and the Clown are minor characters. Without Roderigo, Iago's villainy would not flourish and 
DOI: https://doi.org/10.24113/ijellh.v8i1.10384

without Emilia, Othello's action would not expedite. Again, it is Emilia who exposes Iago before Othello. Bianca, too, has her role. In short, the minor characters are so closely integrated in the plot, that the extrication of any will damage the entire structure of the play.

Cassio, a minor character, who is introduced to us in this opening scene where lago is resenting the fact that his merits as a proven soldier have been sidelined, and Cassio, an "Arithmetician" who has no experience of actual warfare and all his knowledge is limited to "theory" has been appointed as othello's lieutenant. But we know with reasonable certainty that Cassio is a competent soldier.

The opening scene forms the exposition of the play. The three persons overtly discussed are, Desdemona, Othelo and Cassio who do not appear in this opening scene. At the same time the general outline of these characters strarts emerging out of the conversation between Iago and Roderigo and a little later from the violent reaction of Brabantio whom Roderigo rouses up with 'a dire yell' and intensifies the speculatory mood of the audience.

In the third scene we are taken to the council chamber of the Duke of Venice. Brabantio accompanies the party to the Duke who with his fellow senators is discussing the state affairs and the intentions of the Turks to attach Cyprus. Brabantio lodges a complaint that the Moor has corrupted his daughter with drugs and charms. He categorically accuses Othello of having used witchcraft in order to ensnare and capture the heart of a woman totally different of him in age, in complexion and in every other respect. In the last scene of the third act, the Clown, who is a minor figure, once again makes his appearance on the stage but only for a short duration. The conversation between the Clown and Desdemona provides dramatic relief to the audience. Emilia plays a pivotal role, first by stealing the handkerchief and second by exposing the evil character of Iago.

We may say that Othello is a great play and almost without equal in the world of Shakespeare. It is a tragedy with a number of distinctive features of its own. Not only the 
DOI: $\underline{\text { https://doi.org/10.24113/ijellh.v8i1.10384 }}$

major characters but also the minor characters are minutely portrayed and accurately described in the play. The play offers, even in its minor characters, a number of unusually full and profound studies of humanity: Brabantio, the sophisticated, civilized Venetian senator, unable to comprehend that his delicate daughter could love and marry a Moor, speaking excitedly of black magic and spells to account for what his mind cannot understand; Cassio, the gentleman soldier, polished in manners and gracious in bearing, wildly drunk and revealing a deeply rooted pride in his ramblings about senior officers being saved before their juniors; the vision of human nature which the play offer is one of ancient terrors and primal drives fear of the unknown, pride, greed, lust-underlying smooth, civilized surfaces - the noble senator, the competent and well-mannered lieutenant, the conventional gentlewoman.

Macbeth

Macbeth is the shortest of Shakespeare's tragedies and it is the most closely-knit of all. It is the greatest effort of Shakespeare's genius and most sublime and impressive drama, which the world has ever beheld. The play is remarkable for its unequalled intensity of poetry, its distinct characterization, and its overwhelming dramatic power displayed throughout the play. In Macbeth one finds a sinewy strength, unity, depth for passion, loftiness of style and rich illustration of characters. The tragedy is equally distinguished for the lofty imagination and vehemence of the action. The overwhelming pressure of a supernatural agency urges on the tide of human passions with redoubled force.

Shakespeare's excels in the openings of his plays, and that of Macbeth is he most striking. The play takes us right into the midst of the action, and the three witches, the instruments of darkness, waiting for the result of the battle that is being waged, arrange to meet Macbeth on a desolate heath. Thus a relationship between the Witches, the minor characters, and Macbeth, the central figure is established at the very outset. The Witches are 
DOI: https://doi.org/10.24113/ijellh.v8i1.10384

brought in early because they have to play a part in the action of the play and settle the fate of Macbeth.

The second scene of the first act introduces many a minor character of the play. As the curtain rises, Duncan the king of Scotland, is seen with his two sons, Malcolm and Donalbain, and Lennox, a nobleman. The king awaits the news of the battle being waged against the Norwegian invaders. A sergeant, stained with blood, arrives to give the latest news of the battle. He goes into raptures while mentioning the heroic deeds of valiant Macbeth. He also pays tribute to the bravery of Banquo, another commander, who has fought side by side with Macbeth. The rest of the story is told to Ross who also comes from the battlefield.

Banquo is strongly contrasted with Macbeth. His words of caution about the prophecies fail to cut any ice on Macbeth. Banquo is greatly surprised that his partner should start as if in fear, and observe that he is at once rapt and he bids the Witches, if they know the future, to prophesy to him. He neither begs their favour nor fears their hate.

The fourth scene shows Duncan as an innocent and trusting person. He shows his sense of gratitude by addressing Macbeth as 'worthiest cousin; by promising to reward Banquo generously, and by honouring Macbeth with a visit to the castle.

The fifth scene is laid in Macbeth's castle at Inveerness. A messenger arrives and announces the visit of the king Duncan to the castle. In this scene the influence of the Witches is clearly seen. The prophecies have tempted both Macbeth and Lady Macbeth. Thus the Witches, the minor characters, continue to affect the tragic action of the play by their evil power.

The sixth scene is poetic, one of those sweetest songs that tell of saddest thoughts. It depicts the final calm before the storm. King Duncan arrives at Inverness in the company of 
DOI: https://doi.org/10.24113/ijellh.v8i1.10384

his sons Malcolm and Danalbain and a few of his noblemen- Banquo, Lennox, Macduff, Ross and Angus. He finds the air around this castle to be very pleasant and wholesome.

The prayer by the old king which closes the scene moves the audience from intense excitement to general reflection. The scene ends with a human and Christian hope that the traditional values will be restored.

The play ends on a note of hope and redemption. The unnatural happenings, the reversal of values, all these are transfigured into a world of moral order. We are inclined to think that Malcolm has 'king becoming qualities' like justice, verity, temperance, stableness, beauty, perseverance, mercy, lowliness and other desirable traits. By 'the grace of Grace' alone Malcolm, who is a minor character, will restore health to Scotland.

King Lear

King Lear has been considered by many as Shakespeare's greatest work, the best of his plays, the tragedy in which he exhibits most fully his multitudinous powers. The minor characters in King Lear are King of France, Earl of Gloster, Edgar, Curan, Oswald, Old man, Doctor, Fool and members of Lear's army. What is significant in the play in the sub plot that runs parallel to the main plot and finally merges into it. The characters, mostly major, act significantly in sub plot and present a world very much like the world of the main plot in a comical way. The jumping of the blind earl is very much like the fall of Lear but it ends comically, whereas of Lear's is tragic.

The tragedy has a double part. The main plot in the play pertains to lead his three daughters, and his two son-in-law . the sub plot pertains to Earl of Gloster and his two sons. In the main plot Lear and his three daughters are the principal figures while Edmund, the illegimate son of Gloster and a villain, is the chief figure in the second plot in various ways. Edgar's feigned madness is the thing which finally overturns Lear's sanity; his Killing of 
DOI: $\underline{\text { https://doi.org/10.24113/ijellh.v8i1.10384 }}$

Oswald provides him with the evidence to expose Goneril's murderous designs against her husband. Gloster is turned by a conflict of loyalties. His loyalty to Lear brings him in conflict with Cornwall. At some time, his connection with Cornwall leads to Edmund's intrigue with Goneril and Regan, an intrigue which has such disastrous consequence for himself as well as for the two sisters.

Though Albany is minor figure but his character is largely determined by the plot. He has to be in love with Goneril in the first half of the play until the recognizes her true nature. He has to be willing to repel a foreign invader, though sympathizing with Lear; and in his denunciation of Goenril he has to wield a genuine moral authority. Even minor characters are nicely designed to conform to the requirements of the plot. Oswald, for example, has to be effeminate, greedy, a go-between and a flatterer, but he is also faithful to his mistress, his lost thought being of the delivery of her letter to Edmund. Another character, so minor that he is not even given a name, is the servant of Cornwall who turns on his master. His action is the turning point of the play.

The scene first of the act second takes us again to Gloster's castle where Edmund is apprised by Curan of the impending visit of Regan and Cornwall of his father's castle. Curan who is a minor character tells Edmund about the possibility of a war breaking out soon between the Duke of Cornwall and Duke of Albany.

It is further to be remarked that in this play the Fool is an important minor character with a distinct place in the cast and a distinct part in the development of the plot. Like Kent he sees through the hypocrisy of the sisters, and recognizes the folly of he king's abdication and partition of his kingdom. His outspoken upbraiding of the king, mixed as it is with so much wise philosophy, forms the most interesting part of the play.

In the scene third of the third act Gloster, who is a minor character, commits the gravest mistake of confiding the secrets of the landing of the Frendh army in some of the 
DOI: https://doi.org/10.24113/ijellh.v8i1.10384

ports of England and of his own active sympathy with Lear both of which intelligences Edmund uses to his advantage and to the complete undoing of Gloster himself, whose eyes are monstrously plucked out by Cornwall.

The first scene of the fourth act we find Edgar, who is wandering all alone on the health. He meets his blind father, led by the Old man. The Old man, a new minor character introduced in this scene, is one of Gloster's old tenants who, out of his sympathy for Gloster in his miserable condition, has offered his service to him. Edgar is surprised and grieved on seeing his father in this condition.

The Scene fourth of the fourth act introduces to us the two new minor characters - A doctor and a Messenger. The doctor is hopeful of Lear's recovery. The role of the Doctor is significant because after his initial efforts Lear is restored to sanity to some extent.

Kent is also a minor character. He is hot and rash but his character is shown with a fine insight.

In the last scene only three minor personages are left on the stage to mourn the great massacre of so many illustrious figures at a single stroke of the eternal executioner deathAlbany, Edgar and Kent. The Last of these, the loyal follower of the king, the great Earl to Kent, also expresses his intentions of not surviving his old master long:

"I have a journey, Sir, shortly to go;

My master calls me, I must say no.” 
DOI: $\underline{\text { https://doi.org/10.24113/ijellh.v8i1.10384 }}$

References:

Booth, Stephen: King Lew, Macbeth, In Definition and Tragedy, New Haven, Yall University Press 1983

Braddley . AC. Shakespearean Tragedy: Lectures on Hamlet, Othello, King ALear, Macbeth, London Macmillan, 1905.

Hazlitt, William Characters of Shakespeare's play Oxford University Press, 1916.

Muir, Kenneth: Shakespeare's source, comedies and Tragedies university Press 1972.

Levi, Peter: The life and Times of William Shakespeare, London, Macmillan. 1988

Honan, Park: Shakespeare. A Life at Oxford, Oxford University Press. 1998

Kyd, Thomas: The Spanish Tragedy 